Eastern Illinois University

The Keep

Faculty Research \& Creative Activity

History

April 2003

\title{
African Americans and Land Loss in Texas: Government Duplicity and Discrimination Based on Race and Class
}

Debra A. Reid

Eastern Illinois University, dareid@eiu.edu

Follow this and additional works at: http://thekeep.eiu.edu/history_fac

Part of the United States History Commons

\section{Recommended Citation}

Reid, Debra A., "African Americans and Land Loss in Texas: Government Duplicity and Discrimination Based on Race and Class" (2003). Faculty Research \& Creative Activity. 72.

http://thekeep.eiu.edu/history_fac/72

This Article is brought to you for free and open access by the History at The Keep. It has been accepted for inclusion in Faculty Research \& Creative Activity by an authorized administrator of The Keep. For more information, please contact tabruns@eiu.edu. 
African Americans and Land Loss in Texas: Government Duplicity and Discrimination Based on Race and Class

\section{DEBRA A. REID}

The number of farmers in the United States declined precipitously during the twentieth century, but minorities, particularly African Americans, have left agriculture at a more rapid rate than white Americans. Between 1920 and 1997, the number of African Americans who farmed decreased by 98 percent, while white Americans who farmed declined by 66 percent. The disproportionate decline affected the ability of minorities to own property, a common aspiration of U.S. citizens who subscribe to the Jeffersonian ideal? that land ownership can secure their economic independence and eventually their political equality. The number of African American landowners peaked during 1910 with 218,972 individuals owning 15,691,536 acres (8,835,857 acres owned free and clear, 4,011,491 acres mortgaged, and 2,844,188 acres owned in part). Between 1910 and 1920, the number of African Americans owning farms declined even though the number operating farms increased, from a total of 893,370 in 1910 to 925,710 in 1920 . Since 1920 , however, the number of farms owned or operated by African Americans has declined steadily in most southern states. 1

Many analysts turn to economies to explain minority abandonment of farming. Economists Roger Ransom and Richard Sutch have argued that African Americans devoted more of their land to cotton, could not sustain soil fertility due to overuse, did not produce necessary foodstuffs or livestock due to the cash-crop concentration, and became the victims of exploitative creditors. A report by the Center for the Study of Human Resources in 1971 argued that the "inability to acquire capital was more important than concentration on small farms in determining the black's survival rate in agriculture." Some, such as Loren Schweninger, looked for a silver lining in the negative statistics. He recognized the "tragedy in the declining fortunes of Negro proprietors in the South," yet he indicated that leaving farming would lead to a brighter economic future for farm youth "who are entering a wide variety of professions and business fields or securing more highly paying jobs in towns and cities." Critics countered this by arguing that economic interpretations oversimplify a complex situation that varied over time and space due to African American landowners' responses to local economic, political, and social situations. 2

Others have considered the ways that racism affected African American land ownership. White southerners intent on restricting African American independence after the Civil War used legislation, terrorism, and economic pressure to control land sales. Vernon Burton's study of one county in South Carolina indicates the ways that African American goals of landownership forced whites to adjust their goals of exploitation. By 1880, four out of ten African American households in Edgefield District, South Carolina farmed and enjoyed a better life than African Americans 
involved in other nonprofessional occupations. Yet the return of white Democrats to political dominance in 1876 reduced the political influence of African American farmers. Thus began an uneasy relationship between African American land-owners who paid taxes and white Democrats loathe to share control. Burton has argued that the loss of political power "radically diminished economic opportunity." This conclusion captures the consequences of racism during the early stages of the African American quest for economic independence based on landownership.3

Case studies of African American landowners and their experiences in the Jim Crow South indicate the ways that some attained economic security but still could not participate in politics and society as equals because of white supremacy. Even economic interpretations acknowledge the importance of considering the ways that landownership empowered African Americans and threatened whites. In 1975, the Black Economic Research Center decided that "to evaluate the importance of owning land solely by economic criteria is to approach the topic with too narrow a perspective." The center concluded that reversing land loss required a threepronged approach: access to information, legal assistance to protect land owned and land to be acquired, and financial assistance to stop fraudulent sales of minorityowned land. The center determined that this assistance could best counter the "great deal of chicanery bordering on the illegal ... regularly practiced by unscrupulous whites against unsuspecting or unsophisticated southern blacks." The center's report allowed that the chicanery "work[ed] to the great disadvantage of the black community because of its poverty if not because of its race," acknowledging the complexity of minority land loss. The small scale of operations certainly affected the rate of loss, with more small farms going out of business between 1930 and 1970 than large farms. Yet sociologists Spencer Wood and Jess Gilbert controlled for farm size and found regardless of the size of the operation a greater percentage of African Americans than whites stopped farming between 1920 and 1997. The two-part assault based on economies and race has destroyed family farming as a viable option for African Americans. 4

Government policy, notoriously biased against small producers and minority farmers, exacerbated the problem. Studies point to the inadequate services provided to African American farmers by the U.S. Department of Agriculture (USDA). Particularly the New Deal programs, such as the Agricultural Adjustment Administration (AAA) and its successor, the Agricultural Stabilization and Conservation Service, failed to serve black and white farmers equally or to support poor farmers. In fact, James Cobb argued that depression-era federal agricultural and relief policies helped Mississippi Delta planters "sustain their social and political domination." But racial discrimination within the USDA began seventy years earlier at its founding in 1862. The department failed to intercede on behalf of African Americans seeking admittance to the state-based land-grant colleges established by the Morrill Act of 1862. During Reconstruction, African Americans believed that the national government should wield influence on their behalf, and this attitude did not die despite the failure of the national government during Reconstruction to protect black citizenship and rights. It took nearly thirty years 
before the USDA responded to African American petitioners seeking access to public agricultural colleges and experiment stations and the right to participate in other USDA programs. Then the USDA passed the Second Morrill Act (1890), which allowed states to segregate African Americans seeking education in agriculture, trades, and household economy into under-funded and inadequately staffed "1890 institutions." Racism and economic competition inspired influential white farmers to lobby for regulatory legislation that protected their interests within the growing nation state, but in practice excluded poor whites, African Americans, and other minorities.5

After 1914, the USDAs Extension Service, operating through state extension services, provided informal education and published information on agriculture and home economies to rural residents. African Americans, regardless of their economic standing, again received inadequate information via underpaid, overworked agents segregated at the 1890 institutions or at other private black colleges. During the 1960s, the U.S. Commission on Civil Rights reported that "the Department has generally failed to assume responsibility for assuring equal opportunity and equal treatment to all those entitled to benefit from its programs," and instead, acquiesced to "local patterns of racial segregation and discrimination." The Civil Rights Act of 1964 did not reverse decades of racial discrimination within the USDA either. Instead, the USDA officials procrastinated in implementing detailed recommendations issued by the U.S. Commission on Civil Rights in 1968 to bring the USDA into compliance with the Civil Rights Act. Subsequent reports provided more detail about continued injustices, particularly on the part of the Farmers Home Administration, the major public lending institution to family farmers. Nor did special needs legislation, passed during the 1970s and 1980s, address the historic injustices that ethnically diverse and economically disadvantaged rural minorities had endured under previous legislation. Even in the wake of the USDAs acknowledgment that it discriminated against African American farmers between 1981 and 1996, and the settlement of the largest class-action lawsuit based on civil rights infringement in the history of the United States, Pigford v. Glickman (1999), equality and justice remain elusive for black farmers. 6

In addition to the inadequate support provided by the national government, African Americans faced economic and racial discrimination at the local and state level. The majority of African Americans in the South lived in rural areas before World War II. Starting in the 1880s, rural progressives across the South, including Booker T. Washington, urged rural African Americans to look for internal solutions to fight poverty, illiteracy, paternalism, injustice, and violence. Landowning farmers and entrepreneurs reorganized rural society by founding fraternal societies and building schools, churches, and businesses to cater to the black clientele. They welcomed the help of private philanthropy to accomplish their mission. Within the communities they built, landowning farmers, stable tenants, and sharecroppers could find support, education, and culture. African Americans pursued this goal as aggressively as racism allowed. Evidence from Texas, however, indicates how economic and 
racial discrimination combined to undermine black farmers at the local and state level.7

Rural reform did not develop evenly across Texas -- evidence of the ways that local attitudes, geography, and demographics affected decisions. For example, just under 490,000 African Americans lived in the state in 1890, accounting for 21.5 percent of its total population, the smallest percentage among the eleven former Confederate states. Yet Texas ranked fourth in the nation in the number of farms operated by African American owners and tenants that same year. The black population did not decline, but white in-migration caused the black proportion to drop to only 17.7 percent in 1910. Then Texas ranked thirteenth in the nation in the proportion of black compared to white residents. By 1940, black Texans accounted for only 14.4 percent of the state's total population (see Table 1). The African American population was concentrated in eighty-three counties in the eastern half of the state, a region equal to the area of either Alabama or Mississippi. People of African descent accounted for over 50 percent of the total population in only eight counties, 25 to 49.9 percent of the population in forty-two counties, and 12.5 to 24.9 percent in thirty-three others. Politicians and local officials in these rural counties reacted in the southern tradition: They generally condoned the intimidation and violence perpetrated by white supremacists against African Americans, and they supported Jim Crow legislation that legalized discrimination and disfranchisement. These efforts to control the black population succeeded only partially because many African Americans found employment in "Heavenly Houston" rather than in northern cities, and they helped subsidize their farming families. While many distanced themselves from southern racism, the most severe decline in Texas's rural black population did not coincide with the Great Migration of the 1910s, but rather with the post-World War II migration. Neither violence nor droughts, floods nor pests, forced a mass exodus. Rather, African Americans persisted in the rural countryside because they chose farming as their occupation. Rather than having it foisted upon them, they valued their rural society and culture and believed that government support could be secured, despite Jim Crow legislation. 8 
Table 1. Texas Population and Percentage Rural, 1870-2000

\begin{tabular}{|c|c|c|c|c|c|c|c|}
\hline Year & $\begin{array}{l}\text { Total Texas } \\
\text { Population }\end{array}$ & $\begin{array}{l}\text { White Population } \\
\text { (\% of total })\end{array}$ & $\begin{array}{c}\text { Black Population } \\
(\% \text { of total })\end{array}$ & $\begin{array}{l}\text { Other } \\
\text { (\% of } \\
\text { total) }\end{array}$ & $\begin{array}{c}\text { \%o of } \\
\text { Total } \\
\text { that } \\
\text { was } \\
\text { Rural }\end{array}$ & $\begin{array}{l}\text { \% of } \\
\text { Total } \\
\text { Black } \\
\text { Popu- } \\
\text { lation } \\
\text { that } \\
\text { was } \\
\text { Rural }\end{array}$ & $\begin{array}{l}\text { Soof } \\
\text { Total } \\
\text { White } \\
\text { Popu- } \\
\text { lation } \\
\text { that } \\
\text { was } \\
\text { Rural }\end{array}$ \\
\hline 1870 & 818,579 & $564,700(69.0)$ & $253,475(31.0)$ & $(0.0)$ & 93.3 & - & - \\
\hline 1880 & $1,591,749$ & $1,197,237(75.2)$ & $393,384(24.7)$ & $(0.1)$ & 90.7 & - & - \\
\hline 1890 & $2,235,527$ & $1,745,935(78.1)$ & $488,171(21.5)$ & $(0.4)$ & 84.4 & 83.7 & 84.6 \\
\hline 1900 & $3,048,710$ & $2,426,669(79.6)$ & $620,722(20.4)$ & $(0.0)$ & 82.9 & 80.8 & 83.5 \\
\hline 1910 & $3,896,542$ & $3,204,848(82.2)$ & $690,042(17.7)$ & $(0.1)$ & 75.9 & 74.1 & 76.3 \\
\hline 1920 & $4,663,228$ & $3,918,165(84.0)$ & $741,694(15.9)$ & $(0.1)$ & 67.6 & 69.9 & 56.3 \\
\hline 1930 & $5,824,715$ & $4,283,419(73.5)$ & $854,964(14.7)$ & $(11.8)$ & 58.0 & 61.4 & 43.7 \\
\hline 1940 & $6,414,824$ & $5,487,545(85.5)$ & $924,391(14,4)$ & $(0.1)$ & 54.6 & 54.6 & 54.6 \\
\hline $1950^{*}$ & $7,711,194$ & $6,726,534(73.9)$ & $977,458(12.7)$ & $(13.4)$ & 37.3 & 37.4 & 37.2 \\
\hline 1960 & $9,579,677$ & $8,374,831(72.6)$ & $1,204,846(12.6)$ & (10.8) & 25.0 & 24.95 & 24.98 \\
\hline 1970 & $11,198,655$ & $9,717,128(86.8)$ & $1,396,605(12.5)$ & $(0.7)$ & 20.3 & 16.4 & 20.9 \\
\hline 1980 & $14,229,288$ & $11,303,054(79,4)$ & $1,704,741(12.0)$ & $(8.6)$ & 20.4 & 11.8 & 22.5 \\
\hline 1990 & $16,986,510$ & $12,774,762(75.2)$ & $2,021,632(11.9)$ & $(12.7)$ & 19.7 & 9.7 & 22.8 \\
\hline 2000 & $20,851,820$ & $14,799,505(71.0)$ & $2,404,566(11.5)$ & $(17.6)$ & - & - & - \\
\hline
\end{tabular}

*The current definition of urban, initiated in 1950, includes all places with a population of 2,500 or more.

SOURCE: Negro Population, 1790-1915, 43-44, 51, 91-92. Negroes in the United States, 1920-1932, 813. Thirteenth Census of the United States, 1910, Vol. 1, Population: General Report and Analysis, 194. Fourteenth Census of the United States, Vol. 1, Population, 1920, 47. Fourteenth Census, Vol. 2, Population, 1920, 99. Abstract of the Fifteenth Census of the United States, 96. Sixteenth Census of the United States, 1940, Population, 763, 765. Census of the Population: 1950, Vol. 2, Characteristics of the Population, Part 43: Texas, p. 63. Eighteenth Decennial Census of the United States, Census of Population: 1960, Part 45: Texas, pp. xiii, 64. Orville Vernon Burton, "Race Relations in the Rural South Since 1945," in The Rural South Since World War II, ed. R. Douglas Hurt (Baton Rouge: Louisiana State University Press, 1998), 56-58.1980 Census of Population, Vol. 1: Characteristics of the Population, Chapter A: Number of Inhabitants, Part 45: Texas, p. 47 lists the total Texas population as 14,229,191, but this figure was corrected to 14,229,288 in Part 45: Texas, p. 46.1980 Census of Population, Vol. 1: Characteristics of Population, Chapter C: General Social and Economic Characteristics, Part 45: Texas, p. 31.1990 Census of Population, General Population Characteristics, Texas, Section 1 of 2, 29. U.S. Census Bureau, Census 2000 Redistricting Data (Public Law 94-171) Summary File, Texas [http://factfinder.census.gov]. 
Several factors affected the experiences of African American farmers in Texas, and some factors reduced the disadvantages that the minority farmers faced in securing and retaining land. The relatively late settlement of the state meant that the plantation economy and culture did not become as entrenched in Texas as it did in other southern states. Geography promoted a diversified system of plantation agriculture that blended stock farming with cotton production during the antebellum era. Even though Texas became the leading cotton-producing state by 1890, production dominated only the blackland prairie region during the 1910s and 1920s. Significantly, the blackland prairie included proportionately fewer African American farm operators than other East Texas counties. The westward movement of cotton out of the Old South and into East Texas, combined with abundant land and relatively large African American populations in East Texas, made it possible for some African American farmers to raise cotton without total domination by white planters. Further, the racial composition of the Texas countryside, including whites and African Americans as well as Mexicans and Mexican Americans, created different racial tensions than those that existed in other parts of the South. This caused white Texans in some parts of the state to favor African Americans as farm operators. In combination, these factors created a more stable landowning class of black farmers. 9

Disparity existed as some farmers capitalized on their resources. They mechanized, commercialized production, and affected policy decisions that increased subsidies for farmers. Most studies stress the ways that the abandonment of labor intensive agriculture displaced poor white and black farmers and agricultural laborers. New Deal programs exacerbated the inequities of southern agriculture and hastened outmigration. But, an elite group of black landlords, a rural talented tenth, emerged who depended on tenant and sharecroppers for year-round labor, developed and sustained black communities as important processing and marketing points for their agricultural commodities, consolidated land, bought machinery and improved stock, and exercised limited political influence. In contrast to these progressive black farmers, small-scale minority farmers depended on their families for labor, as did their white peers. They focused their energies on raising cotton, the cash crop that drove East Texas agriculture until the Great Depression, but could not do so on a scale that gave them any market leverage. Finally, they expended their energies on supporting community institutions, such as churches and schools, rather than engaging in capital intensive agriculture characterized by land acquisition, mechanization, and market-oriented production.10

These minority farmers shared the liabilities of small-scale farming with their white peers. Many small farmers owned land with low valuations, which limited their ability to capitalize on their operations. Therefore the small-scale farmer, regardless of race, chose not to invest in new equipment, use commercial fertilizers, or increase yields with new varieties and cultivation techniques, all of which amounted to visible proof of "progress" in the opinions of commercial farmers and reformers. And, in decisions that were critical for their future, small-scale farmers often 
inherited family farms but did not secure clear title to the farm land, and in turn, they did not will it to a single heir. Instead they expected the property to remain in common family ownership. Also, agricultural reformers such as extension agents and policymakers considered the diversified approach to farming that small producers practiced as obsolete. White farmers, however, had a distinct advantage over black farmers: they fit within the majority culture of Texas. African American farmers existed outside this majority culture despite the goals and concerns they shared with their white peers.11

African American farmers faced additional challenges because of their race. They had been lobbying for the right to participate in government educational offerings since the late nineteenth century, but momentum increased after 1903 when Cooperative Demonstration Work began in Texas. The work originated in response to the boll weevil infestation that moved into Texas from Mexico in 1894, and then spread to the rest of the cotton-growing South. Yet the slowness with which government officials offered services to black farmers, just as debilitated by the weevil as white farmers in Texas, indicates the bias of government programs against minority farmers. While farmers in other parts of the South may have abandoned depleted fields after the onslaught of the weevil, Texans benefited from the westward migration of the cotton crop, and they increased demands for services. Finally, in 1914, the Smith-Lever Act authorized federal appropriations to states to improve agriculture and rural life throughout the nation. Administrators at the Texas Agricultural Extension Service (TAEX), only after receiving assurance that they would control federal monies allotted for extension work in the state, started the "Negro division" in 1915 to serve African American farmers.12

Segregation provided information and advice that both helped and hurt rural African Americans. Officials who wanted to stern the outmigration of rural black southerners that exploded during the late 1910s believed that extension services could accomplish that, but only some African American farmers qualified for the attention. Across the South, black extension agents targeted landowners, those who deserved the services of the federal and state governments and could best implement the advice. This gave black landowning farmers who chose to participate the latest information on scientific agriculture, soil conservation, livestock care, and management strategies. Yet it left outside the information loop many owners as well as most tenants, sharecroppers, and agricultural laborers. Only the few African Americans who participated received any benefits. Black agents also relayed a contradictory message to many clients. They promoted diversification, a rational step toward economic stability that could sustain small-scale, undercapitalized farmers. But the strategy also constrained black farmers because it discouraged many from investing their limited resources in riskier commercial agriculture. Thus, diversification isolated many minority farmers from extension programs directed toward commercial farmers, mostly white, and served by white agents.13

The African American agents of state and federal government, caught between the black farmers seeking support and the white governments seeking compliance, 
contributed to the problem. Some agents in Texas, all of whom had vocational or college training in agriculture or home economies, came from other southern states and alienated some farmers who could not accept advice from outsiders. To counter the obstacles, many agents proved innovative in their programs and involved farm families in program planning and delivery, thus ensuring the participation of greater numbers of rural African Americans. Yet because the agents were expected to document "progress" to their superiors, they directed their energies toward farm families who had a chance of succeeding. Furthermore, African American agents accepted subordinate positions in a segregated agency, funded by federal monies but administered by Texas authorities. They worked out of the Prairie View Normal and Industrial College (now Prairie View A\&M University), a traditionally black land-grant institution. White legislators and TAEX administrators never gave the black agents everything they wanted; yet despite their marginalized and underfunded positions, they built a bureaucracy that affected white opinion. The positions and influence that the agents attained became as precious to some as the services they had been hired to provide to black farmers. By 1924, the TAEX's Negro division received more federal money than did the segregated divisions in any other southern state and employed as many or more employees. The agents effectively lobbied white Texans to continue services even as segregated services in other southern states lost public support. The agents' minority status, however, prevented them from changing the extension services' preference for commercial agriculture or from defeating pernicious racism. 14

African Americans debated the economic solutions open to them given the limitations imposed on them by disfranchisement. Farmers and agents disagreed over the best actions to take because they approached the problems from different perspectives the farmers as entrepreneurs, who wanted to prosper, compared to the agents of the state, who wanted to sustain their bureaucracy and keep blacks on the farm. Black agents believed that "the Negro is naturally a farmer, that he can best serve society and be the happiest on the farm, and that farm ownership makes for good citizenship." The majority of rural blacks did not own land, however, but this did not affect their decision to farm. Most worked for wages or a share of the crop from the 1910s to the 1930s, a period when fluctuating commodity prices and high inflation rates hurt owners and tenants alike. During the crisis of the 1930s, extension agents responded to financial woes by intensifying their advice to diversify production and invest limited resources in land. Agents argued that diversification provided a means to break out of the cycle of landlord dependency and debt. Tenant contracts prohibited diversification but bound farmers to grow cotton or corn, the crops that most benefited the landlord. Tenants also chose different capital investments than land. By buying draft animals, equipment, or automobiles, they could rent more land, raise more cotton, and become more involved in the market. Tenants who had the resources often chose not to pay the asking price for over-valued land nor invest in substandard but inexpensive land. Most African Americans lived in areas with some of the lowest land values in the state. In 1930, acreage in parts of East Texas, where many blacks lived, was assessed at figures comparable to that in the arid west; counties such as Tyler averaging 
$\$ 5.69$ per acre. Six of the eight counties where African Americans constituted more than 50 percent of the population had land values of less than ten dollars per acre. Tenants chose not to invest in land with such low values and low potential. Yet according to the state agents, frugality and hard work should lead to land ownership. To them, the tenants' decisions made no sense or represented a waste of limited resources.15

Evidence supported the agents' claim that landownership provided security. In 1930, nearly 64 percent of black owners had operated their farms for more than ten years compared to 79.5 percent of black tenants, who had operated their leases for four years or less (Table 2). Most African American extension agents directed their services toward the owner-operators because they had a proven track record based partially on their permanent residence on a farm they owned. Landowning blacks paid county taxes, and their opinions mattered to county commissioners, who responded to their requests for local funding to secure the services of black agents. As a result, agents worked in many but not all of the counties where black landowning farmers accounted for 40 to 60 percent of the total number of landowning farmers, and in more than half of all counties where black landowning farmers accounted for 20 to 40 percent of all landowning farmers (Figure 1). This indicates the limited but real leverage that black farmers and bureaucrats wielded in Texas.16

Table 2. Years of African American Farm Operator Occupancy in Texas, 1930

\begin{tabular}{lcccccc}
\hline & $\begin{array}{c}\text { Total } \\
\text { Reporting } \\
\text { (\% of total) }\end{array}$ & $\begin{array}{c}\text { Less than } \\
\text { One } \\
\text { Year }(\%)\end{array}$ & $\begin{array}{c}\text { One Year } \\
(\%)\end{array}$ & $\begin{array}{c}\text { Two to } \\
\text { Four } \\
\text { Years }(\%)\end{array}$ & $\begin{array}{c}\text { Five to } \\
\text { Nine } \\
\text { Years }(\%)\end{array}$ & $\begin{array}{c}\text { Ten Years } \\
\text { and More } \\
(\%)\end{array}$ \\
Owners \& & 19,747 & 939 & 1,001 & 2,323 & 2,868 & 12,616 \\
Managers & $(95.3)$ & $(4.8)$ & $(5.1)$ & $(11.8)$ & $(14.5)$ & $(63.9)$ \\
All Tenants & 63,341 & 20,182 & 12,272 & 15,557 & 8,328 & 7,002 \\
& $(96.9)$ & $(31.9)$ & $(19.4)$ & $(24.6)$ & $(13.1)$ & $(11.1)$ \\
\hline
\end{tabular}

SOURCE: Negroes in the United States, 1920-1932, 607-08.

Landownership gave farmers of both races freedom of choice that tenants and sharecroppers did not enjoy. Landowners could plant the crops they wanted in the quantities they wanted. Yet most farmers in Texas concentrated on cotton, the crop that could quickly generate revenue for them to expand their operations or improve their material comfort. African American agents cautioned against depending on such an unstable market crop because it jeopardized the farmers' operations. Breaking the all-cotton habit, however, proved beyond the power of the extension agents, even though they made concerted efforts. The 1930 census counted 85,940 black farm operators (including full and part owners), tenants, and managers, the peak for black farm operations in Texas. African Americans operated 17.4 percent of 
all farms in the state. That year the cotton crop in Texas broke all previous records with 3,793,392 bales produced. In 1930, the glutted cotton market collapsed, and government regulation of agricultural production gained momentum. Thereafter the flight from the land began in earnest.17

The economic depression that gripped the United States throughout the 1930s hurt Texas farmers regardless of race. Franklin Delano Roosevelt's New Deal promised economic relief, but the aid failed to live up to its potential because racial discrimination affected decisions. New Deal administrators who excluded African Americans from planning and administration included black extension agents only in implementation. White Texans expected the black agents, both male and female, to provide information about the New Deal programs to their constituents. The agents' sponsorship made it possible for those blacks involved with the extension service to realize some benefits, but it did little for those who chose not to participate or who lived in counties where white authority figures did not support county agents. The black agents insured themselves against failure by channeling aid to farmers with proven track records, and they increased their visibility by accepting appointments to advisory groups. Each new role that the black agents assumed -- each farm that they helped an operator improve, each tenant that they convinced to stay on the land -- represented a small victory. This helped some farmers, but more important for the extension agents, it gave them an opportunity to bolster the reputation of the segregated service and create a niche for themselves within the largest public welfare program undertaken in the United States to date. The strategy, however, did not help poorer farmers in the least, and it hastened African American flight from rural Texas.18

One New Deal agency, the Agricultural Adjustment Administration (AAA), urged farmers to reduce production to stabilize prices. Because crops were already in the fields in Summer 1933 when the agency initiated reduction programs, federal officials launched a series of plow-up campaigns. The major southern plow-up concentrated on cotton, and government officials had to convince farmers in Texas, the leading cotton producing state, to participate to ensure the program's success. TAEX officials knew that they needed the help of black extension agents to implement the program because African American farmers learned about such programs only through the black agents. John Lusk, the African American agent in Washington County, reported that he worked with the white agricultural agent to interest at least 500 farmers in the reduction program, or 31.8 percent of black farmers in the county. The public meetings that Lusk called included a countywide gathering on 30 June in the district court room in Brenham. The black agent in Gregg County, R. G. Johnson, spent less time on the emergency work, only five days, but he reportedly conducted 185 meetings, responded to 75 office visits from interested farmers, and helped 252 farmers apply and secure the production reduction contracts. Given this level of participation, Johnson reached at least 20.7 percent of the black farm operators in the county, and they plowed up 1,242 acres of cotton.19 


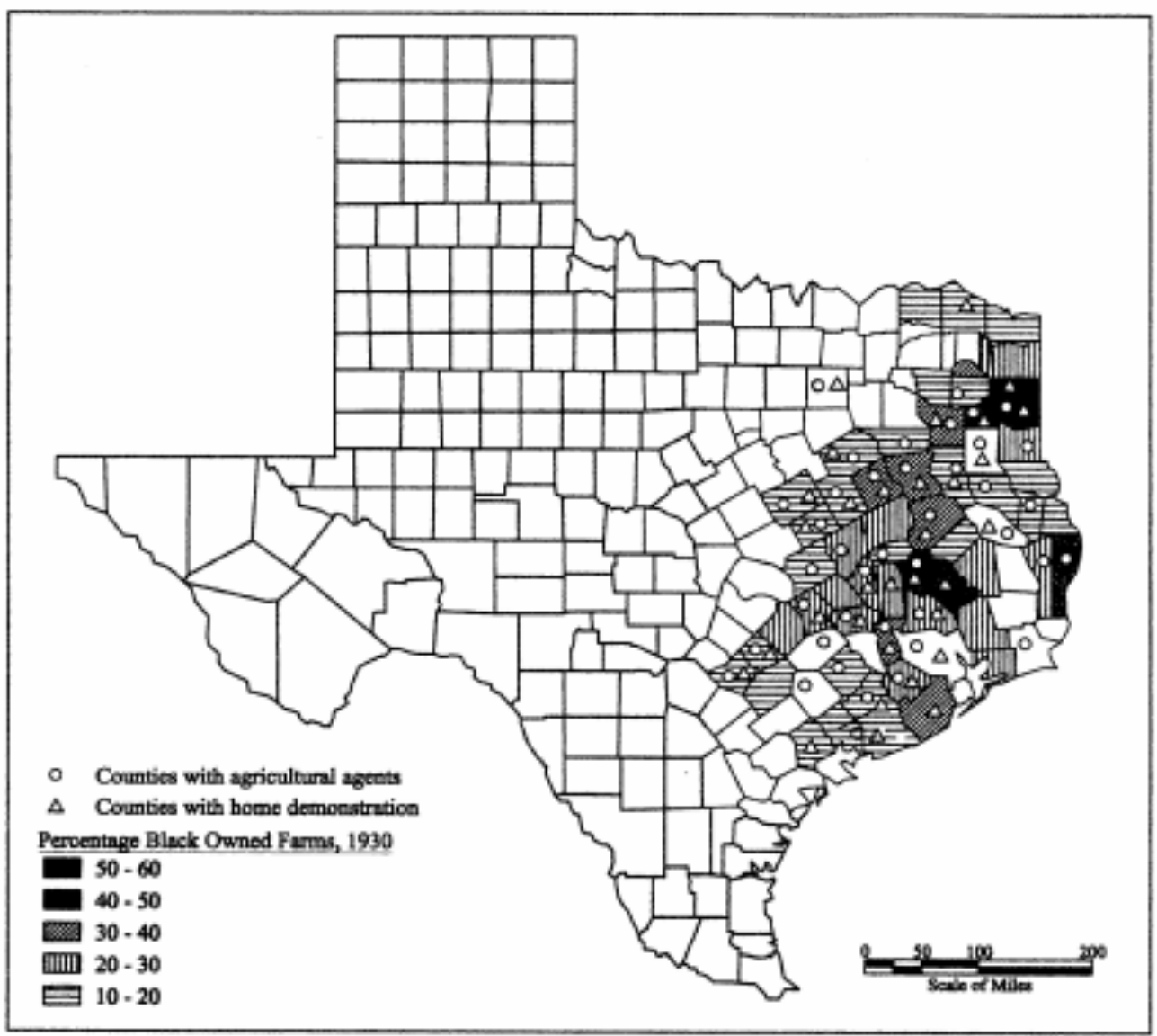

Figure 1: Relationship of African American Farm Ownership, 1930, to the Employment of African American Extension Agents, 1925-1934

Source: Negroes in the United States, 1920-32, 813-27, County Personnel, box 13, 14, and 15, TAEX Historical Files.

A total of twenty-three black county agents in Texas worked on the campaign in 1933. They met with 14,680 families, 17 percent of the black farm operators in the state, in an attempt to convince them to participate. These farmers plowed up 187,323 acres, but this amounted to only 4.3 percent of the $4,350,565$ acres that Texans ultimately destroyed. This percentage indicates the small amount of Texas farmland that black farmers controlled, and concomitantly, the AAA's bias against black farmers. Furthermore, black farm operators received only $\$ 835,529$, or 2.1 percent, of the $\$ 39,225,000$ paid in cotton acreage reduction contracts to Texas farmers. This indicates the disparity in the 1933 AAA payment structure that privileged landlords over plow-up enrollees. The 1934 and 1935 AAA payment structures made the problem even worse. 20

Despite the inequities in the government program, many minority agents of the state found more to praise than to fault in the campaign. According to one home demonstration agent, AAA did what the agents could not do: it freed farm families 
from the burden of an "all cotton" crop. In 1939, Lea Etta Lusk wrote that "now since each farm can plant only a limited amount of cotton, the families are farming on a more scientific basis. They are planting more legumes and cover crops producing more cotton with less expense, which means a saving in feed, labor, and implements. The land released from cotton has given them a chance to plant a larger acreage in food for the family, and feed for the stock, as a result we have better filled pantries and barns, producing more joy and contentment." Agents continued to advocate material improvements as acreage went out of cotton production. Lusk noted that most families used the "Conservation parity checks" for home improvement. The agricultural agent in Walker County, K. H. Malone, reported that farmers used their "increased earnings" to buy farm equipment and land, improve their homes, and pay back taxes and notes. AAA may have helped some farmers, but it left the majority totally unserved.21

The laudatory reports that agents and their supervisors filed deceived readers, masking the real crisis that transformed the countryside during the Great Depression. The rate of mechanization increased during the 1930s, making yearround tenants obsolete. Farmers turned to migrant laborers to work during the chopping and harvest seasons; tenants and sharecroppers were hard pressed to find enough work to remain in agriculture. Unfair distribution of cotton plow-up payments exacerbated the cash shortfall and small farmers, black and white alike, got no justice through the appeals process. All complaints went to county committees composed of white landlords or their sympathizers. When asked why tenants and sharecroppers did not sit on the committee, a county agent quipped, "Hell! You wouldn't put a chicken on a poultry board, would you?" Many farmers remained silent rather than criticize landlords or government officials because they knew that the county committees would rule against them and possibly retaliate. Others, however, shared their dissatisfaction with federal representatives. Tenants and croppers of Mexican as well as African ancestry who worked in the plantation region of the Brazos River Valley during 1933 complained so persistently that the special AAA inspector in Texas, A. A. Allison, urged Cully A. Cobb, director of the AAA Cotton Section, to do "something" to get cotton benefits to them. Residents of Fort Bend, a gulf coastal county, benefited from all-black self-help initiatives, such as the Farmers' Improvement Society of Texas, as well as the services of black extension agents. Fort Bend sharecroppers wrote to Secretary of Agriculture Henry A. Wallace and asked for the federal government to intervene. They refused to sign their names, however, because "they [the landowners] are hard on us about writing Washington, D.C." Cedar A. Walton, the black agricultural agent in Dallas County, testified before the Farm Tenancy Committee in 1937 that black sharecroppers had no support in that north-central Texas county. The bureaucracy offered no resolution; the national government vested decisions in local white control. Economic hardship, the complicity between the federal government and local officials who impeded justice, and a healthy distrust of educated agents of the government who refused to get their hands dirty, caused many white and black farmers to leave the land in disgust. 22 
Obviously, the government programs placed small-scale, non-landowning farmers in an even more precarious position than landowners. Of all farm operators in Texas in 1930, only 4.2 percent were blacks who owned their land; 13.2 percent were black tenants. By 1935, the percentage of owners remained steady, but the number of tenants had dropped to 10.2 percent, an indication that land ownership provided some stability. These few black farmers controlled a minuscule amount of Texas acreage. In 1930, blacks accounted for 17.4 percent of farmers but operated only 3.7 percent of the farmland. By 1935, black operators had dropped to 14.3 percent of the total in the state, and they farmed only 2.8 percent of the land. By 1940, the number of black owners had increased, and they and the tenants who remained had enlarged the size of their holdings (Table 3 ). Yet white landlords controlled not only the remaining 97.2 percent of Texas land, but also much of the land that black tenants farmed. The small farms that African Americans cultivated, their involvement with tenancy, the racism that limited their political involvement, and county agents' concentration on the landed, all conspired against the majority of black farm operators. The government subsidies failed to change these pernicious characteristics of southern agriculture. 23

Table 3. African American Farm Operators in Texas, 1910-1940

\begin{tabular}{|c|c|c|c|c|c|c|c|}
\hline Year & $\begin{array}{c}\text { African } \\
\text { American } \\
\text { Farm } \\
\text { Operators } \\
\text { in Texas }\end{array}$ & $\begin{array}{c}\% \\
\text { Owners* } \\
\text { and Part- } \\
\text { Owners }\end{array}$ & $\begin{array}{c}\text { Average } \\
\text { Size } \\
\text { in Acres } \\
\text { Held by } \\
\text { Owners* } \\
\text { \& Part- } \\
\text { Owners }\end{array}$ & $\begin{array}{l}\text { Value of } \\
\text { Land } \\
\text { PerAcre }\end{array}$ & $\begin{array}{c}\% \\
\text { Tenants* }\end{array}$ & $\begin{array}{l}\text { Average } \\
\text { Size } \\
\text { in Acres } \\
\text { Held by } \\
\text { Tenants }\end{array}$ & $\begin{array}{l}\text { Value of } \\
\text { Land } \\
\text { Per Acre } \\
\text { Held by } \\
\text { Tenants }\end{array}$ \\
\hline 1910 & 69,816 & 30.3 & - & - & 69.5 & - & - \\
\hline 1920 & 78,597 & 29.9 & 76.3 & - & 69.9 & 46.6 & - \\
\hline 1925 & 81,726 & 24.3 & 73.7 & - & 75.7 & 41.6 & - \\
\hline 1930 & 85,940 & 23.9 & 71.1 & $\$ 23.13$ & 76.0 & 44.9 & $\$ 38.75$ \\
\hline 1935 & 71,785 & 29.0 & 66.3 & $* *$ & 71.0 & 46.6 & *** \\
\hline 1940 & 52,753 & 38.1 & 66.4 & - & 61.8 & 51.4 & - \\
\hline
\end{tabular}

SOURCE: Negro Farmers in the United States, 27, 30, 39, 43, 50-55, 79; Negroes in the United States, 1920-1932, 583; Fifteenth Census of the United States: 1930, Agriculture, Vol. II, Part 2-The Southern States, 35, 1382. Foley, The White Scourge, 66-61; Charles H. Hall, Progress of the Negro in Texas, 6. U.S. Census of Agriculture, 1935, Vol. 1, Statistics by Counties with State and U.S. Summaries, 742,764.

Sixteenth Census, 1940, Agriculture, Vol. 3, General Report, 188.

*Negro Farmers in the United States does not define "Owner" or "Tenant," but similar data in Negroes in the United States, 1920-1932, 583, indicate that "Owner" combines full and part owners; "Tenant" combines cash, share and other tenants. Managers are not included in the percentages. Managers accounted for 0.2 percent 
of all operators in 1910; 1.2 percent in 1920; less than 0.1 percent (45 operators) in 1925; 0.1 percent (88 operators) in 1930; and 0.1 percent (28 operators) in 1940.

**The combined value of land and buildings totaled $\$ 1,355$ for black farm owners and \$1,192 for black farm tenants in 1935. Hall, Progress of the Negro in Texas, 6. In 1935 , the value of land per acre in black farms averaged $\$ 23.60$. U.S. Census of Agriculture, 1935, Vol. 1, Statistics by Counties with State and U.S. Summaries, 764.

Other New Deal programs besides AAA provided assistance to black farmers, who needed credit just as much as white farmers. Limited collateral made it difficult for poor farmers of either race to secure loans, and inflation made a loan through a lending agency almost as risky as a traditional crop lien. The Farm Credit Act created the Farm Credit Administration (FCA) to reform farm credit. All federal agencies extending credit to farmers consolidated under FCA, including Federal Land Banks, Intermediate Credit Banks, and Crop Production Offices operated by the USDA. Since 1929, the latter had offered seed loans to black farmers, who had maintained excellent repayment records. Seed loans remained a popular item for farmers even as AAA attempted to reduce crop production. Black agents who helped farmers apply for these loans and plan repayment reminded them not to become dependent. Nevertheless, relief programs that offered loans appealed to African Americans who needed to refinance mortgages, and agents succumbed to their wishes and sponsored their applications. The Emergency Farm Mortgage Act of 1933 helped at least four farmers in McLennan County. The Federal Emergency Relief Act of 1933 also channeled aid toward black farmers.24

The idea of a special credit bureau for African Americans did not gain support from the USDA in 1933 because Secretary of Agriculture Wallace believed that agricultural credit rested with the FCA. Nevertheless, black farmers continued to request consideration. The Texas "Negro" extension service supervisors discussed this at a staff meeting in 1937, recommending "the establishment of a Credit Rating for farm people as well as agents in their respective counties." The FCA targeted black extension agents as a means to reach more farmers and reduce the number who lost their farms due to foreclosure, believing this approach could also serve to reduce the incidents of unfair treatment based on race. The FCA representative King told black supervisors to have farmers write him directly and to provide details. 25

The Bankhead-Jones Farm Tenant Act of 1937 offered another opportunity to smallscale African American farmers, but it never realized its potential because so few loans reached the needy. Intending to alleviate rural poverty, the act made rehabilitation loans available for farmers to ward off land loss and for tenants to buy land. The Farm Security Administration (FSA) oversaw Bankhead-Jones funds. The New Deal agency employed a black advisor, Joseph H. B. Evans, a specialist in race relations, as well as black personnel to work with resettlement projects. By 1938, approximately 21 percent of all families approved for FSA loans were black. Yet from the start of the allocations in 1937 until 30 June 1940, only 162 black families in Texas received these loans, and they averaged smaller loans than white families: 
blacks $\$ 606$, whites $\$ 659$. Also, FSA favored those with the greatest potential for rehabilitation. Detailed enrollment forms helped officials screen applicants; only those with good credit histories and personal commitment qualified.26

As with other USDA programs, local and state committees distributed the funding and services. Calvin Waller, the state leader of the segregated TAEX division, chaired the FSA "Committee for Negroes" in Texas, thus ensuring the involvement of county and home demonstration agents in referring satisfactory clients for the resettlement projects. Regular staff meetings at Prairie View A\&M facilitated this arrangement. Henry Estelle, a Negro district agent, reported to Negro extension supervisory staff about the counties the FSA planned to use to settle tenants and the process by which Negro clients would be selected. The district agents then relayed the information to the "colored" agents in their respective areas. The farmers that agents recommended were usually admitted into the projects. 27

The limited relief available through New Deal programs did not satisfy the desperate need of most rural African Americans and generally thwarted those with the greatest need. Three things exacerbated the inequity. First of all, the federal government did not provide enough resources to satisfy demand. Secondly, the administrators directed the aid toward handpicked recipients, not the neediest. Finally, the administrative structure channeled information on relief and recover programs through the state extension offices, and representatives affiliated with those offices made the selections. As a result, farmers and their families with a history of extension involvement gained an advantage in the application and selection process. This eventually trickled down to those African Americans involved in the extension service, but it left most rural blacks out of the loop. Many owners, tenants, and sharecroppers could not secure loans because they had no history of involvement with the extension program and failed to make the grade. The same applied to poor whites. The welfare state discriminated on the basis of race and class, thus "deserving" African Americans were under-served compared to their deserving white peers, and those deemed undeserving lost out entirely.

The staff of the segregated TAEX took advantage of the prestige they gained through their involvement in New Deal programs to sustain the program throughout World War II and the Cold War. Those served by the extension remained a rather exclusive group. Only about 7.7 percent of the rural black population regularly paid dues to extension clubs, home demonstration, or 4-H clubs and participated in official extension activities. But the service became more inclusive during the late 1930s as the agents advertised meetings and expanded offerings to appeal to general audiences. By 1940, agents reported that they reached nearly 42 percent of all black Texans through their work with soup kitchens, curbside markets, and county health campaigns -- meaningful programs not threatening to the status quo. Nevertheless, black administrators used the statistics to increase public recognition of their service and strengthen their bureaucracy. 28 
Between 1941 and 1945, the agency grew as a result of wartime funding, but allocations proved inadequate. Although Texas added fifteen African American county extension workers to the payrolls, seven counties ceased to host agents. By 1946, 108 agents (56 men and 52 women) worked in at least 56 counties assisting residents in planning and implementing better farming practices and methods to improve rural life. Only Mississippi employed more agents (110), and only North Carolina received more total funds than Texas to support extension work for African American farmers. The support provided to the Texas extension was disproportionately large compared to the number of black farmers in the state, yet still inadequate to respond to the needs of farm operators. In 1940, Mississippi had the highest proportion of black to white farmers in the nation (64 percent); North Carolina ranked fifth (35 percent), and Texas ranked seventh (17.1 percent). By 1950, the decreasing proportion of black farmers indicated the extent of outmigration. Mississippi remained first (53.7 percent), North Carolina had moved to second (28.3 percent), and Texas remained seventh in the nation (11 percent). The funding secured by black extension agents in Texas sustained the bureaucracy and channeled service to the farmers who participated.29

Agents concentrated on improving stock and furthering patriotic endeavors during the war. Sears, Roebuck and Company, located in Dallas, assisted stock improvement goals by providing purebred pigs, chicks, and heifers to club members either selected by county agents or judges at stock shows. The poverty of East Texas counties made it difficult for members there to participate, even though Sears gave away pigs. Agents persevered, however, and by 1946, the Sears Cow-Hog-Hen Program extended to Houston, Newton, Harrison, Rusk, and Smith counties in East Texas.30

The improvement of breeds aided national initiatives such as victory drives and the Farm Labor Program; the extension service helped establish the programs. Eugenia Adeline Woods, previously a home demonstration agent in Walker, Milam, and Montgomery counties, served as (state emergency) food specialist at Prairie View from May 1943 to November 1945. She and other African American district agents and administrators presented radio broadcasts to encourage African Americans to "save and share." Other African American agents received emergency food assistant appointments and along with county agents encouraged residents in fifty-one counties to increase production for the patriotic cause. Others worked to reduce labor shortages caused by war industries and the draft. Two TAEX staff members received appointments to the federal Farm Labor Program. Included were William Cullen David, previously an extension agent in Madison County and district agent, who became "Negro" state farm labor leader, and John Vinson Smith, previously an agent in McLennan County, who became the assistant state labor leader. The staff appointed to war-related positions within extension remained TAEX employees after the war. They had gained valuable experience, which they applied in their leadership roles after their special service ended. Their dedication helped the "Negro" extension service division in Texas to survive the post-war years.31 
The relative success of these black extension agents during the post-World War II years belies the problems that assailed rural African Americans in Texas after World War II, causing them to leave their farms in droves. The rural black population declined by 41.3 percent, from 504,281 in 1940 to 296,250 in 1960 (Table 1), and the number of black farm owners declined even more rapidly, by 71.6 percent, from 52,725 in 1940 to 14,994 in 1960. The steepest decline occurred between 1950 and 1960 when 20,000 left farming -- a 56.3 percent decline over the decade. African Americans fled tenancy and sharecropping fastest between 1940 (32,610 farmers) and $1960(3,138)$, when their numbers declined by 92.4 percent. Only 628 African Americans remained tenants in Texas in 1970.32

As the number of rural Texans declined, the segregated service had to adjust its programming to reach new audiences. The Cold War gave the TAEX a much-needed boost by providing an opportunity for agents of both races to promote patriotism, rural economic development, and civil defense. The "Negro" extension service division strengthened services to urban residents as well, responding to the demographic shift in the African American population. This sustained the growth of the extension service into the 1960s. One of the initiatives involved including the general public in program planning, facilitated by meetings in public places such as courthouses and schools. Extension agents also involved veterans in vocational education in the interest of stemming the outmigration. The most active training occurred in counties with strong extension programs; black agents helped connect veterans to vocational instructors, much as black agents interested farmers in AAA programs during the New Deal era.33

As African American extension agents worked within Texas counties to sustain programs despite rapid declines in the number of black farm operators, African Americans kept policymakers at the national level attentive to issues of racism. By 1941, black educators and writers demanded the integration of the USDA. The criticism prompted action, and Claude A. Barnett, director of the Associated Negro Press, and Dr. F. D. Patterson, president of Tuskegee Institute, received appointments as special assistants to the Secretary of Agriculture in fall 1942. The appointments, however, did not reverse discriminatory practices. The Associated Negro Press proved influential in lobbying efforts, with Barnett taking a leadership role. He urged W. C. David, the Texas Negro division leader, and other black extension service leaders to provide him with information on the agricultural situation in their state. Barnett intended for African American presses to use the information to keep the Secretary of Agriculture, C. F. Brannan (1948-1953), informed about "our principal needs and most urgent problems." Barnett described Brannan as having "a fine and constructive interest in Negro farmers." The pressure kept the USDA from forgetting about rural African Americans. In addition to funding conferences to discuss issues, federal extension officials integrated the staff. They promoted John W. Mitchell, a regional USDA field agent, to the position of "national leader" in September 1953. He became the "first colored Extension worker" to receive such an appointment. The job change required Mitchell to move from his headquarters at Hampton Institute, Virginia to the USDA offices in Washington, D.C., 
where he could more effectively counsel federal extension staff on ways to "develop and strengthen the work with Negro farm families and 4-H club youths." Yet these highly visible public relations moves and durable funding to the segregated division did not reduce the incidents of discrimination that most black farmers encountered daily.34

By 1964, the segregated TAEX employed 104 professional staff members working in sixty counties. This staffing nearly equaled the 1946 level (108 agents in fifty-six counties). Obviously the bureaucracy did not experience an outmigration comparable to that of the black farmers. On 2 July 1964, Texan and President Lyndon Baines Johnson signed the Civil Rights Act. It required all federally assisted programs to eliminate discrimination, and it prohibited job discrimination based on race, religion, national origin, or sex. The equality promised by the Civil Rights Act of 1964, however, failed to trickle down to the Negro division of the TAEX in a timely manner. In fact, the act worked against the black extension agents because TAEX officials used the legislation to eliminate, rather than strengthen, services to African Americans.

The transition year began with the death of the Negro division's state leader, Marshall V Brown, on 22 January 1964. TAEX officials never filled the position. Instead they manipulated titles to protect the status of white agents in the face of pending civil rights legislation. As a result, "Negro" agents became "associate" agents. Title VI of the Civil Rights Act, issued on 11 December 1964, forced TAEX officials to take further action. They developed a single line of administration by eliminating the Negro division entirely and absorbing agents from the division's three districts into several TAEX districts. They left the associate district agents stationed at Prairie View A\&M and did not integrate the TAEX headquarters at Texas A\&M University, justifying the decision by citing examples of white agents and supervisors who worked out of district offices.35

Southern extension service directors generally believed that African American agents would not jeopardize their positions to protest the actions. They learned, however, that some agents had reached the limits of accommodation. John E. Hutchison, TAEX director, underestimated the opposition. He acknowledged that "some few ... might try to encourage certain radical groups to put pressure on the Extension Service and Texas A\&M University to be publicly critical of many programs which might be interpreted as being possibly discriminatory against Negro participants." In reality, black agents did not readily accept the separate offices, subordinate titles, and lower pay and benefits. Preston E. Poole, agricultural agent in Galveston County, Texas, was dissatisfied with TAEX responses to the Civil Rights Act of 1964 and challenged the federal Extension Service (ES) to reinterpret the relationship between federal-state-county authorities. Poole believed that the federal government should require local officials to extend equal pay and office space and require Texas officials to enforce the spirit of the act.36 
The USDA officials condoned discrimination in Texas' extension service and refused to interfere with the TAEX decision-making and implementation process. In fact, they did little more than field complaints from agents about continued segregation and discrimination. Lloyd Davis, the ES administrator, justified the decisions to ignore black agents' requests for mediation for humanitarian reasons. Davis claimed that swift federal enforcement of the integration law would lead to the firing of black agents who were funded partially by local appropriations and housed in offices secured by county governing boards. Even though the USDA created an administrative position to assist the secretary with civil rights compliance in 1965, the wheels turned slowly; many agents (including Poole) did not resolve claims until the early 1970s. This reduced African American access to government information and programs because it created unstable working conditions that lasted until 1972 when most southern states finally integrated their extension headquarters. African Americans criticized the decisions.37

Even efforts to correct generations of inequity backfired. During the 1960s, the federal government documented the unfamiliarity of most black producers with government farm programs. The reports supported new policies to address racial exclusion, often by creating separately funded programs to serve economically disadvantaged and ethnically diverse populations. Yet a belief that the problems of racial inequality had been solved led to perpetual under-funding and ineffective implementation of special needs legislation. This contributed to a new wave of outmigration during the late 1960s and 1970s that crippled remaining black farmers.38

As the officials at TAEX and ES headquarters contemplated integration, a talented young African American from southeastern Texas gained the experience and education he needed to integrate the service and provide needed programs. Dempsey Seastrunk began as a Jasper County agricultural agent in 1948; he was transferred to Prairie View A\&M to work as a farm and home development specialist in 1959, and continued in that position until 1972. He entered the Ph.D. program in cooperative extension administration at the University of Wisconsin-Madison in summer 1964, and after he completed coursework in 1967, TAEX officials gave Seastrunk an office at TAEX headquarters in College Station. His thoughtful approach to involving marginal income farmers fit the growing interest in special services for under-served audiences and proved popular with TAEX and farmers alike. After he completed his dissertation in 1972, TAEX officials appointed him to the position of assistant director for special programs, operating out of the College Station headquarters. In this capacity, Seastrunk implemented a new program designed to improve the income position of small farmers. The Agricultural Act of 1971 (Public Law 92-73) codified this new offering. The act vested Prairie View A\&M and 1890 land-grant institutions throughout the South with full authority for the new "Small Farm Program." Autonomous extension programs were thereby created to serve economically disadvantaged and ethnically diverse populations throughout the South separate from the bureaucracies at white land-grant colleges.39 
On 1 April 1972, TAEX selected an extension agent, Hoover Carden, trained at Prairie View University, to administer the new project. He served for 23 years. Previously Carden had worked with black farmers in Marion County, creating some concern on the part of TAEX officials and white participants because he motivated farm youth and integrated $4-\mathrm{H}$ shows at the state level. Special needs legislation made it possible to promote him to a position administering an autonomous program, but one effectively segregated from the resources that TAEX possessed. The Cooperative Extension Program at Prairie View A\&M University received additional support on 29 September 1977, when the Cooperative Extension Work Act was passed. The federal legislation increased funding to 1890s institutions through the USDA and the federal extension program. Thereafter, these programs became the 1890 Cooperative Extension Program. They served low-income rural and urban African Americans and other ethnic groups but did not discriminate on the basis of socioeconomic level, race, color, religion, national origin, sex, or handicap. Some black agents found positions within the 1890 program, while others worked out of TAEX headquarters on the Texas A\&M campus at College Station. As black agents retired from TAEX, white agents generally replaced them. 40

African American farmers did not find their needs served by the new program, and the decline in the number of black agents working for the "integrated" TAEX operating out of College Station made many leery of seeking advice and assistance from white agents. Frustrated by the hesitancy to provide equal resources, experienced county extension agents took further action. Eight years after his initial complaint, Preston E. Poole, the Galveston County agent, launched a class action suit that charged TAEX with discrimination in employment. Poole believed that two groups of people suffered because of chronic discrimination: the black employees of TAEX and "those blacks who receive[d] the services provided ... to the agricultural community." The resulting consent decree satisfied the complaints of the first group, the black employees, because TAEX voluntarily adjusted its pay scale to reflect merit and service, not race. The interests of the second group, African Americans seeking the services of TAEX, did not affect the decree and remained unaddressed.41

But some African Americans managed to hold onto their farms despite the preferential treatment afforded to white farmers. The inequities not resolved in Poole v. Williams continued, and eventually more southern black farmers charged the USDA with discrimination documented between 1981 and 1996. The case of Pigford v. Glickman was settled by consent decree in January 2001. The USDA agreed to offer restitution to African American farmers who proved that the agency did not respond to their applications for loans and other services on the basis of race. The Federation of Southern Cooperatives/Land Assistance Fund and other black farm support organizations have criticized the government, however, for delayed decision-making regarding claims and denying nearly 40 percent of the claims. Finally, the Associated Press released a series on black land loss in December 2001 that acquainted a larger audience with the inequities. Black farmers could claim chronic discrimination perpetrated by the USDA since the department's 
founding in 1862. Their efforts thus far have prevented the extinction of black farms, but the legacy of self-help goals provided loopholes that made it possible for discrimination to continue through special legislation. As a result, black farmers struggle to gain equitable services to sustain their livelihood and preserve their way of life.42

The effect of the Pigford decision is not yet known. Imtially, black farmers and activists considered it a major challenge to institutionalized racism. Yet, the offered settlements have left them frustrated and critical of the government's compliance. Some minority farmers in Texas, however, have managed to persevere throughout the 1980s and 1990s. In fact, the number of full and part owners and tenants increased modestly in number but significantly in proportion, from 3,292 in 1982, 10.5 percent of all black-operated farms in fifteen southern states, to 3,462 in 1997, 20.2 percent of the southern total. This increase in numbers in one state combined with the legal recognition of discriminatory practices, the viability of less intensive capitalized farming, and laws that safeguard their property may stabilize the interests of African Americans in the countryside.43

\section{FOOTNOTES}

1. Spencer D. Wood and Jess Gilbert, "Returning African American Farmers to the Land: Recent Trends and a Policy Rationale," Review of Black Political Economy 27 (Spring 2000): 44; Negro Population [in the United States], 1790-1915 (Washington, D.C.: Government Printing Office (here-after GPO), 1918; reprinted, New York: Arno Press and The New York Times, 1968), 571,574. Of the total owning land, 211,087 were in the South, 7,498 in the North, and 387 in the West, 572; The Negro Farmer in the United States, Fifteenth Census of the United States: 1930, Census of Agriculture (Washington, D.C.: GPO, 1933), 37; Pamela Browning, The Decline of Black Farming in America: A Report of the United States Commission on Civil Rights (Washington, D.C.: Commission on Civil Rights, 1982), 3.

2. Roger Ransom and Richard Sutch, One Kind of Freedom: The Economic Consequences of Emancipation (New York: Cambridge University Press, 1977), summarized by Manning Marable in "The Land Question in Historical Perspective: The Economies of Poverty in the Blackbelt South, 1865-1920," in The Black Rural Landowner-Endangered Species: Social, Political, and Economic Implications, ed. Leo McGee and Robert Boone (Westport, Conn.: Greenwood Press, 1979), 6-11. The U.S. Commission on Civil Rights relied heavily on this interpretation for its report, The Decline of Black Farming in America, 14-20. Virgil L. Christian, Jr. and Pepelasis Adamantios, "Farm Size and the Displacement of Black Farm Families in Southern Agriculture," Human Resource Development in the Rural South [report] (Austin: Center for the Study of Human Resources, University of Texas, Austin, 1971), quoted in Robert S. Browne, Only Six Million Acres: The Decline of Black Owned Land in the Rural South (New York: Black Economic Research Center, 1975), 33; Loren Schweninger, "A Vanishing Breed: Black Farm Owners in the South, 16511982," Agricultural History 63 (Summer 1989): 41-59; Peggy G. Hargis, "Beyond the 
Marginality Thesis: The Acquisition and Loss of Land by African Americans in Georgia, 1880-1930," Agricultural History 72 (Spring 1998): 241-62.

3. Orville Vernon Burton, "African American Status and Identity in a Postbellum Community: An Analysis of the Manuscript Census Returns," Agricultural History 72 (Spring 1998): 213-40; Mark R. Schultz, "The Dream Realized?: African American Landownership in Central Georgia Between Reconstruction and World War Two," Agricultural History 72 (Spring 1998): 298-312; Valerie Grim, "African American Landlords in the Rural South, 1870-1950, A Profile," Agricultural History 72 (Spring 1998): 399-416.

4. Browne, Only Six Million Acres, 24, 49-51; Wood and Gilbert, "Returning African American Farmers," 43-64.

5. James C. Cobb, The Most Southern Place on Earth: The Mississippi Delta and the Roots of Regional Identity (New York: Oxford University Press, 1992), 208; Elizabeth Sanders, Roots of Reform: Farmers, Workers, and the American State, 1877-1917 (Chicago: University of Chicago Press, 1999), 148-19, 153-54, 334-35.

6. U.S. Commission on Civil Rights, Equal Opportunity in Farm Programs: An Appraisal of Services Rendered by Agencies of the United States Department of Agriculture (Washington, D.C.: GPO, 1965), 100; U.S. Commission on Civil Rights, "The Mechanism for Implementing and Enforcing Title VI of the Civil Rights Act of 1964," in Congressional Record: Proceedings and Debates, 91st Cong., lst sess., 1969, 115, pt 10: 13456-65; Browning, The Decline of Black Farming in America, 176-88; Joel Schor, "The Black Presence in the U.S. Cooperative Extension Service Since 1945: An American Quest for Service and Equity," Agricultural History 60 (Spring 1986): 137-53. Jeannie M. Whayne charted the discriminatory practices of the extension service in Alabama in "Black Farmers and the Agricultural Cooperative Extension Service: The Alabama Experience, 1945-1965," Agricultural History 72 (Summer 1998): 523 -51. Valerie Grim focused on discriminatory practices in two USDA agencies in "Black Participation in the Farmers Home Administration and Agricultural Stabilization and Conservation Service, 1964-1990," Agricultural History 70 (Spring 1996): 321-36. Timothy C. Pigford, et al. v. Dan Glickman, Secretary, The United States Department of Agriculture, Defendant, 185 F. R. D. 82, 1999 U.S. Dist. Lexis, 5220. The district court's consent decree appears at http:// www.usda.gov/da/consent/htm.

7. Debra A. Reid, "Rural African Americans and Progressive Reform," Agricultural History IA (Spring 2000): 322-39. Louis R. Harlan has provided the most comprehensive study of Washington's ideology and influence in Booker T. Washington: The Making ofa Black Leader, 1856-1901 (New York: Oxford University Press, 1972) and Booker T. Washington: The Wizard of Tuskegee 19011915 (New York: Oxford University Press, 1983). Dewey Grantham, Southern Progressivism: The Reconciliation of Progress and Tradition (Knoxville: University of Tennessee Press, 1983); Jack Temple Kirby, Darkness at the Dawning: Race and 
Reform in the Progressive South (Philadelphia: J. B. Lippincott, 1972), 3, described dichotomous progressivism as representing either "decentralizing, democratic, agrarian, and localist interests in provincial America ... [or] urban-based, professional-minded, bureaucratizing and centralizing [thinking of] futurists ... in the new 'public service' state governments during the late 1910s and the 1920s." George R. Woolfolk has described the importance of diversified funding as a dangerous and delicate balancing act to sustain black education: "W. R. Banks: Public College Educator," in Black Leaders: Texans for their Times, ed. Alwyn Barr and Robert A. Calvert (Austin: Texas State Historical Association, 1981), 149.

8. Texas includes 245 counties. Negro Population, 1790-1915, 49, 127, 831-34; Negroes in the United States, 1920-1932 (Washington, D.C: GPO, 1935; reprinted New York: Arno Press \& The New York Times, 1969), 3; Sixteenth Census of the United States, 1940, Vol. 2, Population, Part 6 (Washington, D.C: GPO, 1943), 763, 765. Leon F. Litwack, Trouble in the Mind: Black Southerners in the Age of Jim Crow (New York: Alfred A. Knopf, 1998), 150-63, 488-94, claimed that "Progress could be an enemy, detrimental to health and personal safety." Those who stayed recognized the need to accommodate the white supremacist system, accepted discrimination as a known evil, and exhibited dogged, if naive, determination that self-help strategies would ultimately triumph.

9. Wood and Gilbert, "Returning African American Farmers," 44, 62, n. 5; Pete Daniel, Breaking the Land, The Transformation of Cotton, Tobacco, and Rice Culture since 1880 (Urbana: University of Illinois Press, 1985), 15-16; Neil Foley, The White Scourge: Mexicans, Blacks, and Poor Whites in Texas Cotton Culture (Berkeley: University of California Press, 1997), 11, 62-63, 65-68. Cameron L. Saffell, "When Did King Cotton Move His Throne (And Has It Moved Back?)," Agricultural History 74 (Spring 2000): 293-301. In 1997, the USDA collected Agricultural Census data, previously undertaken by the U.S. Department of Commerce. This provided more accurate counts, but made comparisons with previous years difficult.

10. For information on changing agricultural practices, cotton, and the government, see Gilbert C. Fite, Cotton Fields No More, Southern Agriculture, 1865-1980 (Lexington: University Press of Kentucky, 1984); Daniel, Breaking the Land, 3-22, 91-109; Jack Temple Kirby, Rural Worlds Lost: The American South, 1920-1960 (Baton Rouge: Louisiana State University Press, 1987). All residents of small-town Texas marched to the beat that cotton set, as Thad Sitton and Dan K. Utley document in From Can See to Can't: Texas Cotton Farmers on the Southern Prairies (Austin: University of Texas Press, 1997). Cotton affected the lives of white, African American, and Hispanic women in similar ways as Rebecca Sharpless has documented in Fertile Ground, Narrow Choices: Women on Texas Cotton Farms, 1900-1940 (Chapel Hill: University of North Carolina Press, 1999). Sharon Ann Holt explored the strategies of minority farmers in "Making Freedom Pay: Freedpeople Working for Themselves, North Carolina, 1865-1900," Journal of Southern History 60 (May 1994): 229-62. 
11. Thomas W. Mitchell, "From Reconstruction to Destruction: Undermining Black Landownership, Political Independence, and Community Through Partition Sales of Tenancies in Common," Northwestern University Law Review 95 (Winter 2001): 501-80. For an assessment of the ways that land ownership defined status among white Texans and excluded most minorities from positions of influence in rural Texas, see Foley, The White Scourge, 9.

12. Debra A. Reid, "Reaping a Greater Harvest: African Americans, Agrarian Reform, and the Texas Agricultural Extension Service," (Ph.D. diss., Texas A\&M University, 2000), 44-67. Studies that list the boll weevil as one of the causes of minority land loss include Daniel, Breaking the Land, 6, 9, 10; Schultz, "The Dream Realized?," 311. Daniel linked the growth of government involvement in agriculture to the boll weevil infestation, and he notes the extension service's interest in stemming migration.

13. Earl Crosby has argued that the frustrations of black county agents resulted from the poverty of their constituents and the mismatch between the subsistence goals of demonstration work and the national trend toward large scale, mechanized production. See Crosby, "Limited Success Against Long Odds: The Black County Agent," Agricultural History 57 (July 1983), 277-88, and Crosby, "Building the Country Home: The Black County Agent System, 1906-1940," (Ph.D. diss., Miami University of Ohio, 1977).

14. Studies of the segregated extension service recognize race as an obstacle to its development, but criticize the service for what it chose not to accomplish. See Karen J. Ferguson, "Caught in 'No Man's Land': The Negro Cooperative Demonstration Service and the Ideology of Booker T Washington, 1900-1918," Agricultural History 72 (Winter 1998): 33-54; Crosby, "Limited Success Against Long Odds," 277-88; Reid, "Reaping a Greater Harvest," 7-9, 68-85, 98-105. For an assessment of the competition between African American public servants in Texas, see Debra A. Reid, "African Americans, Community Building, and the Role of the State in Rural Reform in Texas, 1890s-1930s," in The Countryside in the Age of the Modern State: Political Histories of Rural America, ed. Catherine McNicol Stock and Robert D. Johnston (Ithaca: Cornell University Press, 2001), 38-65.

15. "Negro Agents Work Toward Farm Ownership," Texas Extension Service Farm News 20 (May-June 1934): 8. Foley, The White Scourge, 14-11. Studies of tenancy rarely consider the strategies of minority tenants. For criticism of the theory that tenants climbed the agricultural ladder during the twentieth century see Jack R. Kloppenburg, Jr. and Charles C. Geisler, "The Agricultural Ladder: Agrarian Ideology and the Changing Structure of U.S. Agriculture," Journal of Rural Studies, 1, no. 1 (1985): 59-72. U.S. Department of Commerce, Bureau of the Census, Thirteenth Census of the United States Taken in the Year 1910, Vol. 7, Agriculture (Washington, D.C.: GPO, 1913), 613.

16. Reid, "Reaping a Greater Harvest," 144-45. 
17. Keith Joseph Volanto, "Ordered Liberty: The AAA Cotton Programs in Texas, 1933-1940," (Ph.D. diss., Texas A\&M University, 1998), 25-30.

18. Reid, "Reaping a Greater Harvest," 184-238. Most critics of the New Deal focus on class discrimination, some focus on race, but a few do both: David E. Conrad, The Forgotten Farmers: The Story of Sharecroppers in the New Deal (Urbana: University of Illinois Press, 1965), 64-82; Donald H. Grubbs, Cry From the Cotton: The Southern Tenant Farmers' Union and the New Deal (Chapel Hill: University of North Carolina Press, 1971), 4-27; Theodore Saloutos, The American Farmer and the New Deal (Ames: Iowa State University Press, 1982), 179-91; Raymond Wolters, Negroes and the Great Depression: The Problem of Economic Recovery (Westport, Conn.: Green wood Press, 1970), 3-82; Harvard Sitkoff, A New Deal for Blacks: The Emergence of Civil Rights as a National Issue, vol. 1, The Depression Decade (New York: Oxford University Press, 1978), 52-54.

19. Volanto, "Ordered Liberty," 66-76. Each extension service county agent prepared an annual report. These reports were microfilmed as the U.S. Department of Agriculture, Annual Narrative and Statistical Reports of the Cooperative Extension Work Demonstration Program, National Archives and Records Administration, Record Group 33, Microfilm Series (T-845 to T-895), Texas (1909-1944), T890 [hereafter cited as Annual Report, county, (year,) reel number, and T number]. Copies of all reels in series T-890 are housed in Texas Agricultural Extension Service, Payroll Services, Texas A\&M University, College Station, Texas. J. M. Lusk, Annual Report, Washington County (1933) reel 90, T-890. Black farmers in Washington County owned or partially owned 397 farms and farmed as tenants on 1,176 more in 1930; R. G. Johnson, Annual Report, Gregg County (1933) reel 86, T-890. In Gregg County, 426 black farmers owned or partially owned their land and 793 were tenants in 1930. Fifteenth Census of the United States: 1930, Vol. 2, Agriculture, Part 2, The Southern States, 1389, 1400.

20. Waller to Warren, 7 November 1934, box 17, C H. Waller Correspondence, John Coleman Library, Prairie View A\&M University, Prairie View, Texas (hereafter PV). For statistics see C H. Waller, Annual Report, Texas (1933) reel 84, T-890; Volanto, "Ordered Liberty," 84. Crosby, "Building the Country Home," 185; Conrad, Forgotten Farmers, 123-35; Grubbs, Cry From the Cotton, 32- 61; Wolters, Negroes and the Great Depression, 27-28; Saloutos, The American Farmer and the New Deal, 188-89; William Joseph Brophy, "The Black Texan, 1900-1950: A Quantitative History," (Ph.D. diss., Vanderbilt University, 1974), 236-37.

21. L. E. Lusk, "Narrative Report, Washington County, 1939," box 15, Texas Agricultural Extension Service Historical Files, Cushing Library, Texas A\&M University, College Station, Texas (hereafter TAEX Historical Files). K. H. Malone, Annual Report, Walker County (1933) reel 90, T-890. 
22. Conrad, Forgotten Farmers, 54-61, 126-35; Foley, The White Scourge, 164-72; Keith J. Volanto, "Burying White Gold: The AAA Cotton Plow-Up Campaign in Texas," Southwestern Historical Quarterly 103 (January 2000): 352-54.

23. Fifteenth Census of the United States: 1930, Vol. 2, Agriculture, Part 2, Southern States, 35, 1382. United States Census of Agriculture: 1935, Vol. 1, Reports for States with Statistics for Counties and a Summary for the United States (Washington, D.C.: GPO, 1936), 742, 764. The percentage of black owners increased slightly to 4.8 percent of all farm operators in 1940, while black tenants declined to 7.8 percent. These black operators controlled only 2.2 percent of all farmland in Texas in 1940 . Sixteenth Census, 1940, Agriculture, 188. For information on the inequity of black farm income, see Wolters, Negroes and the Great Depression, 7-8.

24. Saloutos, The American Farmer and the New Deal, 181; Wolters, Negroes and the Great Depression, 24-21. The Wilson administration began seed loans with a wartime fund in 1918. The extension service administered them, but opposed them. Only small amounts were loaned, $\$ 150$ to $\$ 200$, and collateral was normally a crop lien. The Federal Farm Loan Board continued loans in the 1920s, and Reconstruction Finance Corporation increased the loans available when approved by President Herbert Hoover. See David E. Hamilton, From New Day to New Deal: American Farm Policy from Hoover to Roosevelt, 1928-1933 (Chapel Hill: University of North Carolina Press, 1991), 154-62; J. V. Smith, Annual Report, McLennan County (1933) reel 88, T-890; "Negro Farmers Have Short Course," Brenham Banner Press, 19 November 1934, RG 33, Records of the Federal Extension Service, Box 47, Texas 1927-1937. Other regular reports concerning field extension work, National Archives and Records Administration II, Chevy Chase, Maryland (hereafter NARA II).

25. Saloutos, The American Farmers and the New Deal, 181; Staff Minutes, 29 September 1937, PV. Staff Minutes, 2 June 1939, PV.

26. For a history of FSA, see Sidney Baldwin, Poverty and Politics: The Rise and Decline of the Farm Security Administration (Chapel Hill: University of North Carolina Press, 1968); Grubbs, Cry from the Cotton, 150-57; Saloutos, The American Farmer and the New Deal, 185-186; Brophy, "The Black Texan," 237-38, 247; Foley, The White Scourge, 180-81. Applications completed by residents of Brazoria County, RG 96, Farmers Home Administration, box 1064, Farmers' Home Administration Rehabilitation Loan Cases, Rural Rehabilitation Loan Case Files, 1934-1944, Records of the County Offices, National Archives and Records Administration Regional Repository, Fort Worth, Texas (here? after FHA, RG 96, NA-FW)

27. Reid, "Reaping a Greater Harvest," 222-28.

28. Lynne Anderson Rieff, '"Go Ahead and Do All You Can': Southern Progressives and Alabama Home Demonstration Clubs, 1914-1940," in Hidden Histories of Women in the New South, ed. Virginia Berhard, et al. (Columbia: University of Missouri Press, 1994), 148. In 1937, black county agents reached 166,720 through 
12,695 club functions as well as informal meetings or contacts with their adult and youth clubs. Of this total, 80,532 attended 6,311 adult demonstrations, 28,397 visited result demonstrations, and 8,512 boys attended extension meetings. Home demonstration agents reached 14,417 women and girls enrolled as club members. H. H. Williamson, Jack Shelton, and Mildred Horton, Annual Report, Texas (1937) reel 110, T-890; Texas Extension Work 1940, 41-44.

29. "1941-1947: Statement of Expenditures for Negro Extension Work," William Cullen David papers, Range 8, Box 6, Folio 12, PV. TAEX Historical Files, Box 13, 14, and 15; Orville Vernon Burton, "Race Relations in the Rural South Since 1945," in The Rural South Since World War II, ed. R. Douglas Hurt (Baton Rouge: Louisiana State University Press, 1998), 56-58.

30. Counties in the Colorado and Brazos river bottoms most frequently participated in the Sears Cow-Hog-Hen Program. See Letter, W. C. David, Prairie View, to E. M. Rechenbrecht [sic], College Station, 10 April 1944, Range 8, Box 5, Folio 14, David papers PV; Letter, E. M. Regenbrecht, College Station, to W. C. David, Prairie View, 20 February 1947, Range 8, Box 5, Folio 38, David papers PV; Report, W. C. David, "Cow-Hog-Hen Project With Negro 4-H Club Boys in Swine Demonstrations, Texas," November 1945-November 1946, Range 8, Box 6, Folio 62, David papers PV.

31. Letter, Jeffie Conner, Prairie View, to Prairie View staff, 7 July 1943, with attached Revised Schedule Radio Broadcasts-1943, Range 8, Box 5, Folio 5, David papers PV; Letter, T. A. Mayes, Austin, Texas, to W. C David, Hempstead, Texas, 7 March 1944, Range 8, Box 5, Folio 13, David papers PV; Letter, Laura Lane, College Station, to W. C David, Prairie View, 27 May 1944, with attached edited radio script, Range 8, Box 5, Folio 16, David papers PV; Letter, C C Randall, Little Rock, Arkansas, to W. C David, Prairie View, 16 June 1944, Range 8, Box 5, Folio 17, David papers PV; Negro District Agricultural Agents, compiled by D. H. Seastrunk, May 1986, in Negro Extension History, folder, PV.

32. U.S. Department of Commerce, U.S. Bureau of the Census, Census of the Population: 1950, vol. 2, Characteristics of the Population, Part 43: Texas (Washington, D.C: GPO, 1952), Part 43, p. 63. Eighteenth Decennial Census of the United States, Census of Population: 1960, Part 45: Texas (Washington, D.C: GPO, 1963), xiii, Part 45, p.64; Burton, "Race Relations in the Rural South," 56-58; Valerie Grim, "The Politics of Inclusion: Black Farmers and the Quest for Agribusiness Participation, 1945-1990s," Agricultural History 69 (Spring 1995): 257-71, concentrated on Class I farmers, those selling more than $\$ 25,000$ in farm products annually. See also Grim, "African American Landlords," 399-416 and "The Impact of Mechanized Farming on Black Farm Families in the Rural South: A Study of Farm Life in the Brooks Farm Community, 1940-1970," Agricultural History 68 (1994): 169-84.

33. Letter, W. C. David, Prairie View, to J. L. Matthews, College Station, 2 May 1947, Range 8, Box 5, Folio 45, David papers PV; Letter, Ide P. Trotter, College Station, to 
W. C David, Prairie View, 13 May 1947, Range 8, Box 5, Folio 46, David papers PV; Farm and Family Life of the Texas Negro Veteran, Bulletin 498, (Austin, Texas: State Board for Vocational Education, November 1949), Range 8, Box 7, Folio 129, David papers PV.

34. Schor, "Black Presence in Extension," 141; Letter, Claude A. Barnett, Director, Associated Negro Press, Chicago, to Paul Appleby, Assistant to the Secretary, USDA, 17 February 1941, RG 16: Office of the Secretary of Agriculture, General Correspondence, Negroes, Box 3: 1940-1955, folder [1941], NARAII; Memo, Thomas N. Roberts, Special Assistant to the Director of Personnel [USDA] to Mr. S. B. Bledsoe, Assistant to the Secretary, 25 November 1942, RG 16: Office of the Secretary of Agriculture, General Correspondence, Negroes, Box 3: 1940-1955, folder [1942], NARA II; Claude A. Barnett, Chicago, to W. C. David, Prairie View, 27 March 1951, Range 8, Box 5, Folio 98, David papers PV; Press release, "Negro Extension Field Agent Promoted to National Leader," USDA Office of Information, Washington, D.C, 7 September 1953, Range 8, Box 7, Folio 145, David papers PV.

35. Biography, Marshall Vernon Brown, Seastrunk's History PV; Letter, John E. Hutchison, College Station, Texas, to Earl Rudder, College Station, 30 December 1964, p. 3, Box 79-16, Texas A\&M University President's Office Records, Cushing Library, Texas A\&M University, College Station, Texas (hereafter A\&M President's Records); "State Leaders of Negro Extension Work, Seastrunk's History PV.

36. Letter, Hutchison to Rudder, 30 December 1964, pp. 3-4, Box 79-16, A\&M President's Records; Letter, John E. Hutchison, College Station, to Earl Rudder, College Station, 2 March 1965, box 79-16, A\&M President's Records; TAEX Salary Register, Reel 1,2,3,4, and 5; Letter, P. E. Poole, La Marquee, Texas, to William M. Seabron, Assistant to the Secretary [USDA], October 1965, RG 16: Office ofthe Secretary of Agriculture, General Correspondence, 1906-1975, Box 4254: Civil Rights Commerce 1966, NARA II. Dissatisfied with the responses he received, Poole launched an official complaint that the USDA forwarded to the Office of the Inspector General to investigate. Letter, William M. Seabron, Assistant to the Secretary [USDA] to Ralph W. Yarborough, U.S. Senate, 30 June 1966, with attachments including the complaint filed 15 June 1966 by Thomas H. Dent, attorney, Galveston, Texas, for Associate County Agents, RG 16: Office of the Secretary of Agriculture, General Correspondence, 1906-1975, Entry 17 U, Box 4455: Civil Rights-Civil Rights 1966, NARA II. Agents in Alabama and Mississippi made similar challenges. See Schor, "Black Presence in Extension," 148-49.

37. Debra A. Reid, "Civil Rights and the Evolution of the 'Negro' Division of the Texas Agricultural Extension Service, 1941-1971" (paper presented at the East Texas Historical Association, Fort Worth, Texas, February 2001). USDA officials justified their refusal to interfere by citing the doctrine of federalism, a concept as old as the U.S. Constitution, which recognizes the authority of a state to care for its citizens without interference from the national government, a right vested to states by the 
Tenth Amendment. Memo, In Reply to the Secretary's Memorandum of June 15 on Implementation of the Civil Rights Bill, from Lloyd H. Davis, Administrator, Federal Extension Service [USDA], to Joseph M. Robertson, Administrative Assistant Secretary [USDA], 19 June 1964, RG 33: Records of the Federal Extension Service, Entry 1002, General Correspondence, 1947-1970, Box 293 [1965], folder: Legislation, NARA II. This memo stressed the authority of states in complying with Title VI of the Civil Rights Act, and the process by which FES would assist. FES responses to claims of discrimination sometimes reminded agents that state extension directors were responsible for employment and other administrative functions, and that many claims did not fall "within the responsibility" of FES in Washington, D.C. For example, see Letter, Lloyd H. Davis, FES Administrator, to Mr. Arthur Britton, Arcadia, Louisiana, 19 January 1965, RG 33: Records of the Federal Extension Service, Entry 1002, General Correspondence, 1947-1970, Box 294 [1965], folder: Criticisms-Complaints, NARA II. Schor documents how integration hurt black programs in "Black Presence in Extension," 148-51.

38. Grim, "Black Participation," 321-36.

39. Letter, Hutchison to Rudder, 30 December 1964, box 79-16, A\&M President's Records. The Registrar, University of Wisconsin-Madison, confirmed that Dempsey Seastrunk defended his dissertation, "Organizational Incentives Associated with Motivation of County Extension Agents Toward Professional Development: A Case Study," and received his Ph.D. degree in December 1972 (conversation with the author, 7 June 2001). Press releases announcing Seastrunk's appointment as an assistant director and his retirement indicate that he assumed a specialist position at TAEX headquarters in 1967. Press Release, Agricultural Extension Service, College Station, Texas, 29 February 1972; "Assistant Director of Ag. Extension to Retire," Press Release, [1986], Seastrunk A\&M. Yet Seastrunk's records indicate that he worked out of Prairie View as a specialist from 15 July 1959 to 1 February 1972. "Negro Extension Specialist," Seastrunk History PV. See Dempsey Seastrunk, "Black Extension Service," The New Handbook of Texas (Austin: Texas State Historical Association, 1996), 1: 567; Public Law 92-73, 10 August 1971, United States Statutes at Large, 1971, Vol. 85 (Washington, D.C: GPO, 1972), 186; John E. Hutchinson, "The Texas Agricultural Extension Service: A Historical Overview," Southwestem Agriculture: Pre-Columbian to Modern, ed. Henry C. Dethloff and Irvin M. May, Jr. (College Station: Texas A\&M University Press, 1982), 132.

40. Dr. Alfred Poindexter, Veterinarian, Prairie View A\&M University, interview by author, 13 May 1999. Impact 1 (March 1984): 4 (newsletter of the Cooperative Extension Program, Prairie View A\&M University).

41. Poole v. Williams, Individually and as President of Texas A\&M University System, et al, no. 72-H-150, 26 January 1974, as corrected 28 January 1974, U.S. District Court, Southern District of Texas, Fair Employment Practice Cases, vol. 7 (Washington, D.C.: Bureau of National Affairs, 1974), 102-04; Schor, "Black Presence in Extension," 149, n. 26. 
42. "A New Season: Black Farmers in Texas Form Group to Take Control of Their Own Destinies," Dallas Morning News, 6 April 1999; Salim Muwakkil, "Grapes of Wrath," In These Times 21 (26 May 1997): 23-25; Salim Muwakkil, "Too Little, Too Late for Black Farmers," In These Times 23 (21 February 1999): 10-11; "Resolution of Black Farmer Law Suit Passed by the Members of the Federation of Southern Cooperatives/Land Assistance Fund at the Annual Meeting in August 2001," Epes, Alabama. [http://www.federationsoutherncoop.com/resolute.htm]. The settlement fell far short of the damages done according to representatives of the Black Farmers \& Agriculturalists Association, Tillery, North Carolina, "Pigford v. Glickman \& the Consent Decree: Why so Many are Losing," BFAA on the Move 1 (May 2001): 2. Charlene Gilbert and Quinn Eli, Homecoming: The Story of African American Farmers (Boston: Beacon Press, 2000), 162-67; Todd Lewan and Dolores Barclay, "Torn from the Land," Associated Press (2001) [http://wire.ap.org/APpackages/torn/]. This multiple-part investigative series explored the importance of property ownership to rural African Americans and the ways racism destroyed their land holdings and influence.

43. Wood and Gilbert, "Returning African American Farmers," 46. 7997 Census of Agriculture, United States Summary and State Data, Vol. 1: Geographic Area Series, Part 51, 524-525. 